2012-10

\title{
An improved micro propagation system for successful transformation of cauliflower (Brassica oleracea var. botrytis).
}

\author{
Al-Swedi, FG \\ http://hdl.handle.net/10026.1/1266
}

10.17660/actahortic.2012.961.19

Acta Horticulturae

International Society of Horticultural Science

All content in PEARL is protected by copyright law. Author manuscripts are made available in accordance with publisher policies. Please cite only the published version using the details provided on the item record or document. In the absence of an open licence (e.g. Creative Commons), permissions for further reuse of content should be sought from the publisher or author. 


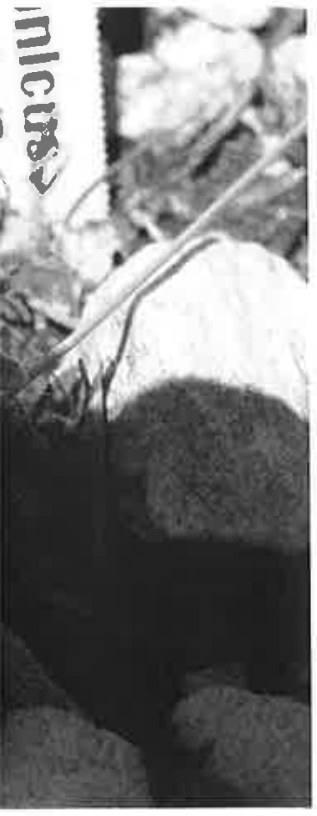

tion in an experimental field.

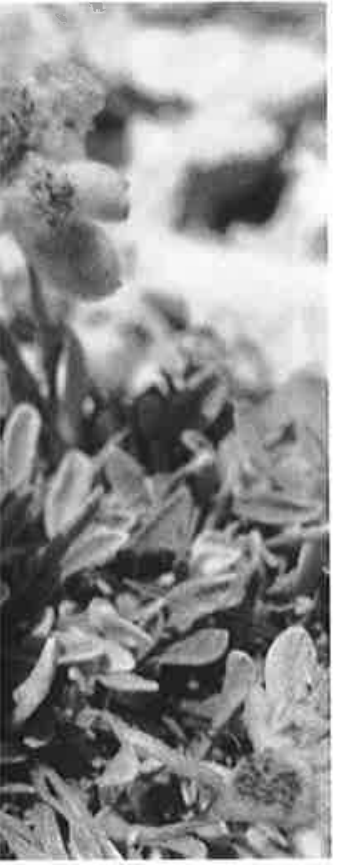

nsplantation in an experimental
An Improved Micro Propagation System for Successful Transformation of Cauliflower (Brassica oleracea var. botrytis)

F.G. Al-Swedi, S. Lane and M.P. Fuller

School of Biomedical and Biological Sciences

Faculty of Science and Technology, Plymouth University

plymouth, Devon, PL4 8AA

United Kingdom

Keywords: cauliflower, micro propagation, Agrobacterium tumefaciens

Abstract

Cauliflower is described as a recalcitrant plant to the genetic transformation process from Agrobacterium. Cauliflower curd meristems were used in a fractionation and sieving protocol to produce microshoots in in vitro culture. This technique produced many thousands of small explants suitable for transfection studies. Explants were successfully transformed following standard transfection with 4. tumefaciens carrying a construct with Kanamycin ${ }^{\mathrm{R}}$, GUS and the Ascorbate peroxidase (APX) gene. Selection using Kanamycin produced normal plant phenotypic plantlets and these putative transformants were confirmed using GUS staining and PCR of the APX gene sequence. The transfection conditions were optimised during this study and 105 Agrobacterium cells/5 plants/pot successfully produced 1 transformed plant/pot.

\section{INTRODUCTION}

Cauliflower (Brassica oleracea var. botrytis L.) is known as one of the most responsive species for tissue culture but one of the most recalcitrant Brassica species for genetic transformation (Passelgue and Kelam, 1996; Puddephat et al., 1996). Therefore the pre-requisite of the present investigation was to optimize an efficient protocol for tissue culture and the main goal was to establish a transformation protocol to integrate the Ascorbate Peroxidase gene (APX) into cauliflower. The most common method used for the transformation of other related $B$. oleracea species and sub-species is Agrobacterium and both $A$. tumefaciens and $A$. rhizogenes have been used to transform a number of other $B$. oleracea crops (Puddephat, 1996). A. tumefaciens-mediated transformation of cauliflower has been attempted with a variety of explants such as hypocotyl, leaf, seed and seedling stem with limited results. Oncogenic Agrobacterium was used with leaf discs by Srivastava (1988) and de Block (1989) but their procedure could not be reproduced in other laboratories (Kazan, 1997; Metz, 1995). Eimert (1992) experimented with the use of Agrobacterium with leaf disc and protoplasts by electroporation, and direct DNA uptake however, irrespective of the method used, stable transformation at very low frequency was reported. A. tumefaciens was used to infect seedling explants (cotyledon and hypocotyl) using a modified procedure of de Block (1989) and the following comments were made: "The present protocol (Clough and Bent, 1998; modified from Bechtold et al., 1993) is extremely simple. We have found that the MS salts, hormone, etc. make no difference, that OD of bacteria doesn't make much of a difference, that vacuum doesn't even make much of a difference as long as you have a decent amount of surfactant present. Plant health is still a major factor - healthy fecund plants make a big difference".

The use of antibiotic in culture media has recently become more widespread with the emergence of antibiotic resistance genes as selectable markers in transformation experiments and in transformation systems. In addition, cocultivation of Agrobacterium tumefaciens requires the use of an antibiotic to kill the bacteria. The antibiotic Kanamycin, Gentamycin and tetracycline have been found to be inhibitory to cell or tissue growth at comparatively low concentrations. Fiolaetal (1990) indicated that the addition of $10 \mathrm{mg} \mathrm{L}^{-1}$ or higher Kanamycin sulphate to Rubus cotyledon regeneration medium drastically

Proc. $7^{\text {th }}$ IS on In Vitro Culture and Horticultural Breeding

Ed.: D. Geelen

Acta Hort. 961, ISHS 2012 
reduced the growth and organogenesis of explants.

\section{MATERIALS AND METHODS}

\section{Plant Material}

The January heading 'Dionis' $F_{1}$ hybrid cauliflower was grown in the field at Plymouth University, Devon, UK, following good commercial practice (Anon., 1982). The curds were harvested and taken to the laboratory where in vitro micro-shoots were produced in liquid culture according to the method of Kieffer et al. $(1995,2001)$ and Rihan et al. (2011). This method produced a high volume of single or double meristem explants in the size range $300-600 \mu \mathrm{m}$.

\section{Agrobacterium tumefaciens}

Agrobacterium tumefaciens (A.t.) strain APX was kindly supplied by the USDA and has been used to investigate the biology of A.t. vectored transformation in other species. The A.t. APX strain used pRTL2 and pCGN1578 as vectors. The T-DNA of PCGN1578 has three $35 \mathrm{~S}$ promoter elements and the construct has a dual CaMV $35 \mathrm{~S}$ promoter as well as a TEV leader and CaMV terminator. It also contained the $\beta$-glucronidase (GUS) reporter gene under the transcription control of Cauliflower mosaic virus $35 \mathrm{~S}$ promoter. The A.t. APX strain was grown in LB media supplemented with Kanamycin and Gentamycin.

\section{EXPERIMENT PROTOCOL}

\section{Experiment 1}

Large pieces of curd $(1-5 \mathrm{~cm})$ were surface sterilized by immersing for $15 \mathrm{~min}$ in $10 \%$ un-thickened commercial bleach (sodium hypochlorite $0.06 \%$ active chlorine) followed by 3 washings in sterile distilled water. Following surface sterilization, explants were produced manually. The first step eliminated the mass of non-responsive tissue (stem branches) by shaving off the upper meristematic layer using a scalpel under sterile conditions in a laminar flow hood. The second step was a mechanical partial homogenization of the selected meristematic tissue using a commercial blender (Waring model 800) at approximately $17000 \mathrm{rev} \mathrm{min}^{-1}$ for $30 \mathrm{~s}$ followed by the use of precision sieves $(600,300,212 \mu \mathrm{m}$ aperture size) to rank the explants into the size classes 212-300 and $300-600 \mu \mathrm{m}$. The culture density was controlled by using a constant volume of explants per container containing $20 \mathrm{ml}$ of culture medium. Eighty to 100 culture containers were used per experiment and incubated on a shaker $\left(<50\right.$ revs $\left.\min ^{-1}\right)$. Culture media were derived from Murashige and Skoog (1962), according to Anderson and Carstens (1977) and supplemented with Kinetin $\left(0.2 \mathrm{mg} \mathrm{L}^{-1}\right)$ and IBA (indol-3-butyric acid $\left(0.1 \mathrm{mg} \mathrm{L}^{-1}\right)$ for the shoot development medium, and IBA only $\left(0.2 \mathrm{mg} \mathrm{L}^{-1}\right)$ and agar $\left(7 \mathrm{~g} \mathrm{~L}^{-1}\right)$ for the rooting medium, Kieffer et al. (1995). Culturing was carried out in the laboratory at $23^{\circ} \mathrm{C}$ with adjacent lighting provided by white fluorescent tubes with a photoperiod of $16 \mathrm{~h}$. The addition of the antibiotic Plant Preservation Mixture (PPM) $\left(1 \mathrm{ml} \mathrm{L}^{-1}\right)$ was routinely added to reduce contamination risk (Fuller and Pizzey, 2001). All media, sieves, instruments and the Waring blender were sterilized by autoclaving at $121^{\circ} \mathrm{C}$ for 15 min.

\section{Experiment 2}

For transformation experiments it is recommended that the bacterial cultures art il the $\log$ growth phase with an $\mathrm{OD}_{600}=0.6$. The growth curve was obtained firom cultures inoculated from actively growing liquid culture $(1 \mathrm{ml}$ culture in $100 \mathrm{ml} \mathrm{LB}$ medis) supplemented with the appropriate combination of antibiotics. The presence of the APX gene construct in A. t.s was confirmed using PCR as follows:

1. Step 1. Bacterial colony template preparation; A.t. (strain APX) was grown in solid if with $20 \mathrm{mg} \mathrm{L}^{-1}$ Kanamycin $+6.0 \mathrm{mg} \mathrm{L}^{-1}$ Gentamycill. 
er was grown in the field ercial practice (Anon., 198 a re in vitro micro-shoots 82 ) effer et al. (1995, 2001) were of single or double meristem

indly supplied by the USDA tored transformation in othe as vectors. The T-DNA struct has a dual CaMV $35 \mathrm{~s}$ nator. It also contained the control of Cauliflower mosai B media supplemented with

by immersing for $15 \mathrm{~min}$ in rite $0.06 \%$ active chlorine), surface sterilization, explants ass of non-responsive tissue $r$ using a scalpel under sterile was a mechanical partial commercial blender (Waring owed by the use of precision into the size classes $212-300$ using a constant volume of ium. Eighty to 100 culture ker $\left(<50\right.$ revs $\left.\min ^{-1}\right)$. Culture according to Anderson and ${ }^{-1}$ ) and IBA (indol-3-butyric A only $\left(0.2 \mathrm{mg} \mathrm{L}^{-1}\right)$ and agar turing was carried out in the iite fluorescent tubes with a Preservation Mixture (PPM) Fuller and Pizzey, 2001). All sterilized by autoclaving at

at the bacterial cultures are in was obtained from cultures Iture in $100 \mathrm{ml} \mathrm{LB}$ media) cs. The presence of the APX APX) was grown in solid or in $+6.0 \mathrm{mg} \mathrm{L}^{-1}$ Gentamycin.

Iture was incubated at $28^{\circ} \mathrm{C}$ in the dark for 24 to 48 hours

The culture PCR Reaction; Plasmids were isolated using a Kit from sigma.com/oligos 2. Step 2. The primers 5'-CACGTCTTCAAAGCAAGTGG-3' (35SCaMV 5 frw), 5'-TT (APX 5) frw and 5'-AAGAGGGCGGAATACAG TCGGAAT-3' (APX 5 rev) were used for the PCR reaction. Each PCR reaction mixture A $T$ T PCR mixture, $2 \mu \mathrm{l}$ DNA, $1 \mu \mathrm{l}$ of each primer forward and $1 \mu \mathrm{l}$ of reverse, $1 \mu \mathrm{l}$ was $50 \mu, 5 \mu \mathrm{l}$ Taq buffer, $2 \mu \mathrm{l} \mathrm{Taq}$ and $38 \mu \mathrm{l}$ deionized autoclaved water. Before starting DNTPS, PCR cycle, the thermo cycler (Gene Amp ${ }^{(8)}$ PCR system 9700) was heated to the first $30 \mathrm{~min}$, and then the sample was heated to $94^{\circ} \mathrm{C}$ for $2 \mathrm{~min}$. This was followed by $95^{\circ} \mathrm{C}$ for of $55^{\circ} \mathrm{C}$ for $1 \mathrm{~min}, 75^{\circ} \mathrm{C}$ for $1 \mathrm{~min}$. In the final cycle, the reaction period at $30 \mathrm{cycles}$ extended to $10 \mathrm{~min} .1 .5 \%$ agarose and $100 \mathrm{ml}$ of $1 \mathrm{x}$ TAE buffer were $75^{\circ} \mathrm{C}$ was mixed and boiled in a microwave oven for 3-4 min, then $2.5 \mu \mathrm{l} \mathrm{SYBR}$ Safe thoroughly stain was used for detection.

DNA gel stain

Experiment 3 Firstly optimization of parameters enhancing transformation efficiency; the high

frequency of shoot regeneration from the curd micro propagation protocol number to be ideal for Agrobacterium-mediated gene transfer. Secondly selection for appeared formation; the explants co-incubated with Agrobacterium were washed for $30 \mathrm{~s}$ plant trans $\mathrm{mg} \mathrm{L}^{-1} \mathrm{Cefotaxime}$ to inhibit Agrobacterium growth, followed by three washes with 250 ilized water. After 5 days of growth in S23 medium with $250 \mathrm{mg} \mathrm{L}^{-1}$ Cefotaxime, with sterilized was assessed using the GUS assay. Explants were then transferred to S23 transform with $20 \mathrm{mg} \mathrm{L}^{-1}$ Kanamycin.

\section{RESULTS}

Effect of different blending durations on explant production; during explant development in agitated liquid medium, the majority of the good quality microshoots were floating at the surface of the culture medium, this is especially obvious when cultured at $22 \pm 1^{\circ} \mathrm{C}$. For the two optimal size-classes the number of responding micro explants in culture for a constant volume of cultured micro explants decreased with blending duration (Kieffer, 1996). The optimal treatment duration to obtain the maximum of responding micro explants was $30 \mathrm{~s}$ for the two optimal size-classes (Fig. 1). The number of well-developed micro explants per container varied between $5-20 \pm 10$ for the $212-300 \mu \mathrm{m}$ and $40 \pm 20$ for $300-600 \mu \mathrm{m}$ size class. The standard culture medium (supplemented with Kinetin $\left(0.2 \mathrm{mg} \mathrm{L}^{-1}\right)$ and IBA $\left.\left(0.1 \mathrm{mg} \mathrm{L}^{-1}\right)\right)$ enabled regeneration of micro shoots which often displayed early signs of polarisation, root hair like structures close to the shoot apex.

\section{Optimum Culture Conditions for Agrobacterium tumefaciens (APX)}

The total mean of high concentration suspension CFU (colony forming unit $/ \mathrm{ml}$ ) was recorded for Agrobacterium tumefaciens strain (APX) growing on LB medium. Significant differences were recorded between the media at $\mathrm{P}<0.001$. A t. strain APX grew faster and gave a more homogeneous suspension in LB medium than YEB. The results showed that LB medium was more suitable for the growth of this strain. LB medium was used thereafter in all transformation experiments.

1. Determination of Agrobacterium tumefaciens Growth on LB Medium. The growth curve shows that, when quantifying bacteria growth via optical density, the maximum growth of A.t. APX strain (1.51) was obtained after $42 \mathrm{~h}$. A classic sigmoid growth curve vas obtained for APX strain and the log phase of growth $\left(\mathrm{OD}_{600}=0.6\right)$ was detected after $20 \mathrm{~h}$. For transformation experiments it is preferable that the culture is still in the log phase.

2. Molecular Analysis of Agrobacterium Plasmid Using PCR. Since PCR amplification is very sensitive, it is imperative that sources of cross contaminating DNA, including extraneous microbes, be avoided. The PCR using the $355^{\prime}$ foreword primer and APX3 reverse primer occasionally yielded 3 bands. The APX encoding sequences were detected 
at 478 bp after PCR amplification.

The effect of high bacterial concentration was also reported by Orlikowska et al (1995), Change et al. (2002) and Ismail et al. (2004). Diluted concentration (1:10 al, $1: 20$ dilution) reduced necrosis to a great extent. In general the results confirmed that and $\left(\mathrm{OD}_{600}=0.6\right)$ bacterial density helped to improve transformation rate. These results agre with Srivestava et al. (1988) and Henzi et al. (2000). Whereas Chakrabarty et al. $(2002)$ obtained maximum transformation efficiency with 1:20 dilution.

Healthy growing explants were transformed with the APX gene using a standard transfection protocol mediated by Agrobacterium. The explants that successfully grew under selection and presenting normal plant phenotypic features were considered putativ transformants. The transfection condition optimised during this study successfully produced 1 transformed plant per culture vessel.

\section{Confirmation of Transformation}

1. Selection of Transgenic Plants. After co-cultivation the infected explants were washed for 30 seconds with $250 \mathrm{mg} \mathrm{L}^{-1}$ Cefotaxime to inhibit Agrobacterium growth. followed by three washes with sterilised distilled water and transferred to S23 medium, with $250 \mathrm{mg} \mathrm{L} \mathrm{L}^{-1}$ Cefotaxime medium plus $25 \mathrm{mg} \mathrm{L}^{-1}$ Kanamycin with $2-4$ weeks most of the untransformed shoots turned either pink or white and no further growth of shoot observed, while transformed shoots remained green on this medium and continued grow (Fig. 2),

2. Histochemical and Fluorescence GUS Assay. Enzymatic analysis revealed Gus activity in explants used in this experiment. Samples taken from putative transformants showed GUS activity which indicated the presence of functional GUS enzymes in regenerated plants (Fig. 3).

3. DNA Analysis (PCR). Polymerase chain reaction was carried out (Fig. 4) to providi. further evidence for the presence of the APX gene in the genomes of transformed plants. In addition, DNA extracted from the A.t. APX strain was prepared and used as a control. DNA from non-transformed cauliflower leaves was used as a negative contiol. PCR results confirmed that a fragment of approx. 478 bp appeared in transgenic plants and $\mathrm{A} . \%$ extracts whilst it was not present in non-transformed plants.

\section{DISCUSSION}

Different precision sieves and blending durations were used and the optimum conditions were $30 \mathrm{~s}$ blending and $300 \mu \mathrm{m}$ sieving (Fig. 1). This produced a large amoun of explants of uniform size suitable for transformation. Meristem destruction increased with increased blending duration, while less than $30 \mathrm{~s}$ did not disrupt the meristem clusters sufficiently.

Several factors are critical for successful production of transgenic cauliflowit One of these parameters is Agrobacterium density which plays an important role in the transformation process. The reduction in transformation rate caused by inoculation with high concentration of Agrobacterium $\left(\mathrm{OD}_{600}=0.6\right)$ appears to relate to an apparent hypersensitivity of explants to Agrobacterium eliciting a pathogenic response rather than a transformation event. Development of an efficient gene transfer system largely depends on a rapid and reliable in vitro regeneration system for the desired plant species and a competent transformation protocol. Even though in our lab a simple methodology allowing the production of ten thousands of micro shoots from curd meristems has been developed which would allow the necessary level of replication for transformation Kieffer et al. (1995) this technique was compromised largely because of bacterial overgrowth. In early experiments no meristems were able to survive the infection with Agrobacterium. 列 al. (2002), Prem and Nicole (1998) and these were assessed in this investigation but found al. (2002), Prem and Nicole (1998) and these were assessed in this investigation buts were obtained if small quantities of Agrobacterium cells from fresh bacterial colonies (onuced two weeks after streaking) were used during transformation with microshoots produce 
o reported by Orlikowska iluted concentration $(1: 10$ al 1 the results confirmed that and nation rate. These results $1: 10$ ereas Chakrabarty et al. (200e lution. the APX gene using a standar explants that successfully grew atures were considered putativ luring this study successfully

on the infected explants were inhibit Agrobacterium growth and transferred to $\mathrm{S} 23$ medium, amycin with 2-4 weeks most of and no further growth of shoo this medium and continued to

zymatic analysis revealed GUS ken from putative transforman of functional GUS enzymes in

is carried out (Fig. 4) to provide genomes of transformed plants. 5 prepared and used as a control. sed as a negative control. PCR ared in transgenic plants and $A . t$. ts.

ns were used and the optimum 1). This produced a large amoun Meristem destruction increased s did not disiupt the meristem

Iction of transgenic cauliflower ch plays an important role in the rate caused by inoculation with pears to relate to an apparent pathogenic response rather than e transfer system largely depends $r$ the desired plant species and our lab a simple methodology ts from curd meristems has been ication for transformation Kieffer ication for transformation Kicth. In he infection with Agrobacterium. Is and cotyledons Chakraberty e sed in this investigation but foun that the most reliable results wer $\mathrm{m}$ fresh bacterial colonies (one to ation with microshoots produced fractionation and grading.

Putatively transgenic plants (carrying APX) were identified by growing on the medium, and these were assayed for the GUS reporter gene. The substrate for US detection, X-Gluc, worked well but the quality of the histochemical localisation was as by numerous variables such as tissue preparation and fixation. The putatively ffectermed plants all showed transient GUS staining and this confirmed this to be an (rans reliable method of establishing optimal conditions of tansformation (Chakry et al., easy re All the GUS positive plants in histochemical assay showed the APX band in 2002). A $\mathrm{ACR}$ analysis.

subsequentese methods are routinely used to evaluate the presence of insert sequences

Thectors harboured in individual Agrobacterium strains and transformed construct (Ping et al., 1997; Jones et al., 1987). Although Perm and Nicole (1998) and plants the case with cauliflower too. PCR is a fast and sensitive method but it is provedy expensive and susceptible to cross-contamination. On the other hand the GUS relative used in this study have advantages as it was simple, required minimal use of astay und plant tissues and did not cause permanent damage to the plant. The present cliemidy provides a reliable transformation system for integration of some genes into the cauliflower genome. This provides an opportunity to introduce genes of agronomic interest such as abiotic resistance.

\section{CONCLUSION}

The fractionation and grading of cauliflower curd meristem tissues gave a reliable method to produce many thousands of clones suitable for a transformation protocol with frobacterium. The results of transformation with APX gene constructs indicated that the insient GUS assay approach is easy reliable method of establishing optimal conditions of transformation. The elimination of Agrobacterium tumefaciens and shoot regeneration by using cefotaxime and carbencillin confirmed that $250 \mathrm{mg}^{-1}$ was the best concentration enhance the regeneration frequency and efficiency and at the same time suppress the Igrobacterium growth. Molecular analysis of Agrobacterium plasmids using PCR can be considered as a routine method to evaluate insert sequence constructed into vectors harboured in individual bacterial colonies and this method substantially reduces time and effort required to evaluate the authenticity of inserts in agrobacterium binary vectors.

\section{ACKNOWLEDGEMENTS}

Fadil Al-Swedi acknowledges the financial support from the Ministry of Higher Education \& Scientific Research, Iraq and the technical staff of the Davy building ( $3^{\text {rd }}$ floor), Plymouth University.

\section{Literature Cited}

Anon. 1987. MAFF report on crops and supplies of fruit and vegetables in England and wales-position. MAFF report 707:25.

Anderson, J.A.W. 1977. Tissue culture propagation of broccoli, Brassica oleracea (Italic Group), for use in $F_{1}$ hybrid seed production. Hortic. Sci. 102:67 73.

Bhalla, P. and de Weerd, N. 1999. In vitro propagation of cauliflower, Brassica oleracea var. botrytis for hybrid seed production. Plant Cell, Tissue and Organ Culture 56(2):89-95.

Bechtold, N., Ellis, J. and Pelletier, G. 1993. In planta Agrobacterium-mediated gene transfer by infiltration of adult Arabidopsis thaliana plants. C.R. Acad. Sci. Paris Life Sci. 316:1194-1199.

Clough, S.J. and Bent, A.F. 1998. Floral dip: a simplified method for Agrobacterium mediated transformation of Arabidopsis thaliana. The Plant Journal 16(6):735-743.

Chakrabarty, R., Viswakarma, N. et al. 2002. Agrobacterium-mediated transformation of cauliflower: optimization of protocol and development of Bt-transgenic cauliflower. Journal of Biosciences 27(5):495-502.

Changhe, Y., Huang, S. et al. 2002. Factors affecting Agrobacterium-mediated 
transformation and regeneration of sweet orange and citrange. Plant Cell, Tissue
Organ Culture $71(2): 147-155$.

De Block M,d.B.D. and Tenning, P. 1989. Transformation of Brassica napus Brassica oleracea using Agrobacterium tumefaciens and the expression of bar and and
genes in transgenic plants. Plant Physiol. 91:694-701. genes in transgenic plants. Plant Phystol.

Prassica oleracea L. var. botrun of cauliflower (Bration an experimental survey. Plant Mol. Biol. 19:485-490.

Fiola, J.A., Hassan, M.A. et al. 1990. Effect of thidiazuron, light fluence rates kanamycin on in vitro shoot organogenesis from excised Rubus cotyledons and leand Plant Cell, Tissue and Organ Culture 20(3):223-228.

M.P. Fuller and Pizzey, T. 2001. Teaching fast and reliable plant tissue culture using pm and Brassicas. Acta Hort. 560:567-570

Kazan, K.C.M., Goulter, K.C. and Manners, J.M. 1997. Agrobacterinm tumefacien mediated transformation of double haploid canola (Brassica napus) lines. Plins
Physiol. 24:97-102.

Kieffer, M., Fuller, M.P. et al. 1995. Rapid mass production of cauliflower propagute. from fractionated and graded curd. Plant Science107(2):229-235

Kieffer, M. 2001. A cost effective protocol for in vitro mass propagation of cauliflowe Plant Science 160(5):1015-1024

Metz, T.D., Dixit, R. et al. 1995. Agrobacterium numefaciens-mediated transformation brocoli (Brassica oleracea var. italica) and cabbage (B. oleracea var. capitata). Plan Cell Repolts 15(3):287-292.

Murashige, T. and Skoog, F. 1962. A revised medium for rapid growth and bio assar with tobacco tissue cultures. Physiologia Plantarum 15(3):473-497

Orlikowska, T.K., Cranston, H.J. et al. 1995. Factors influencing Agrobacteriun tumefaciens-mediated transformation and regeneration of the safflower cultivin 'Centennial'. Plant Cell, Tissue and Organ Culture 40(1):85-91.

G. Ismail, H.S. and Zogluer, K. 2004. Agrobacterium mediated transformation of Lar decidua, an assessment of factors influencing the efficiency of Gus gene transfit. Applied Botany 78(2):83-90.

Henzi, M.X., Christey, M.C. et al. 2000. Factors that influence Agrobacteriun thizogenes-mediated transformation of broccoli (Brassica oleracea L. var. italica) Plant Cell Reports 19(10):994-999.

Jones, J.D.G., Gilbert, D.E. et al. (1987). T-DNA structure and gene expression in petuni: plants transformed by Agrobacterium tumefaciens C58 derivatives. Molecular alli General Genetics MGG 207(2):478-485.

Passelègue, E. and Kerlan, C. 1996. Transformation of cauliflower (Brassica oleracen var. botrytis) by transfer of cauliflower mosaic virus genes through combined cocultivation with virulent and avirulent strains of Agrobacterium. Plant Science 113(1):79-89.

Ping, X., Dae-Jin, Y., Paul, M. and Ray, A. 1997. An expedient and reliable method in identify gene constructs in Agrobacterium vector. Plant Tissue Culture and Biotechnology 3:37-40.

Prem, L.N.S. 1998. Agrobacterium tumefaciens-mediated transformation of cauliflower. Brassica oleracea var. botrytis. Molecular Breeding 4:531-541.

Puddephat, I.J., Riggs, T.J. et al. 1996. Transformation of Brassica oleracea L.: a criticil review. Molecular Breeding 2(3):185-210.

Rihan, H.Z., Al-Issawi, M., Burchett, S. and Fuller, M.P. 2011. Encapsulation of cauliflower (Brassica oleracea var, botrytis) microshoots as artificial seeds and theil conversion and growth in commercial substrates. Plant Cell, Tissue and Organ Cultur: 107(2):243-250.

Smirnoff, N. and Colombe, S.V 1988. Drought influences the activity of the enzymes 0 the chloroplast hydrogen peroxide scavenging system. .J. Exp. Bot. 39(8):1097-1105

Srivastava, V., Reddy, A.S. et al. 1988. Transformation and regeneration of Brassict oleracea mediated by an oncogenic Agrobacterium tumefaciens. Plant Cell Reports 7(7):504-507. 
range. Plant Cell, Tissue a ion of Brassica napus the expression of bar and and ca oleracea L. var. botrytis): ron, light fluence rates and Rubus cotyledons and leaves lant tissue culture using Agrobacterinm tumefaciens rassica napus) lines. Plant

on of cauliflower propagules $29-235$.

stopagation of cauliflower.

$s$-mediated transformation of leracea var. capitata). Plant rapid growth and bio assays :473-497.

influencing Agrobacterium of the safflower cultivar $85-91$.

ated transformation of Larix iency of Gus gene transfer.

it influence Agrobacterium a oleracea L. var. italica).

d gene expression in petunia derivatives. Molecular and

lower (Brassica oleracea var: ough combined cocultivation t Science 113(1):79-89.

dient and reliable method to Plant Tissue Culture and

ansformation of cauliflower, -541 .

assica oleracea L.: a critical

P. 2011. Encapsulation of 5 as artificial seeds and theit Il, Tissue and Organ Culture e activity of the enzymes of Exp. Bot. 39(8): 1097-1108. nd regeneration of Brassica efaciens. Plant Cell Reports
Figutes

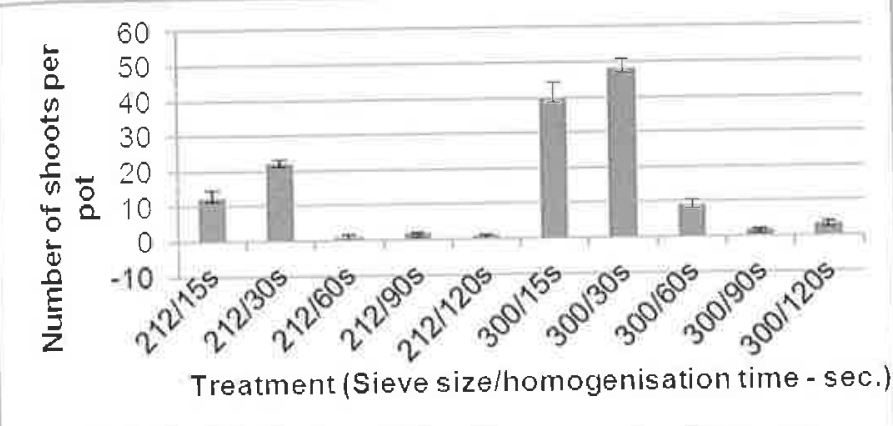

Fig, 1. The effect of different sieve sizes and duration of blending on number of explants produced

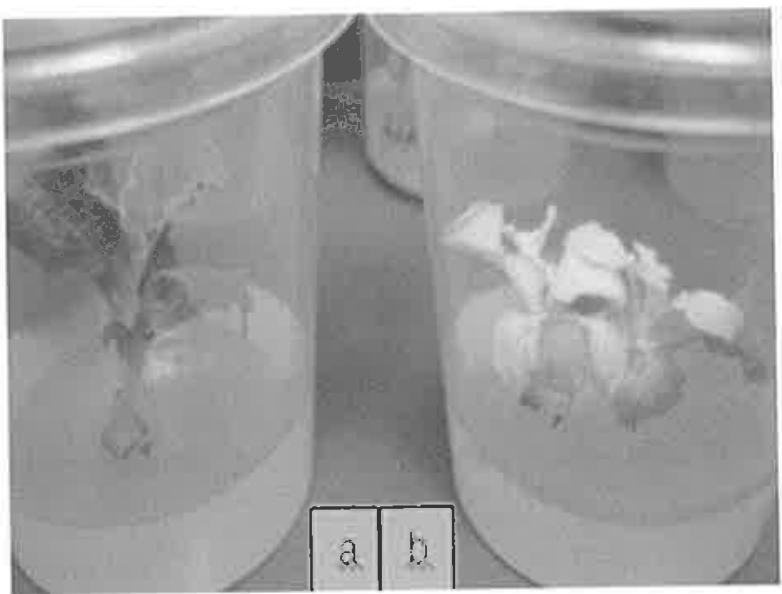

Fig. 2. Selection of transformed plants infected with APX strain: (a) transgenic plant; (b) non-transgenic plant. 


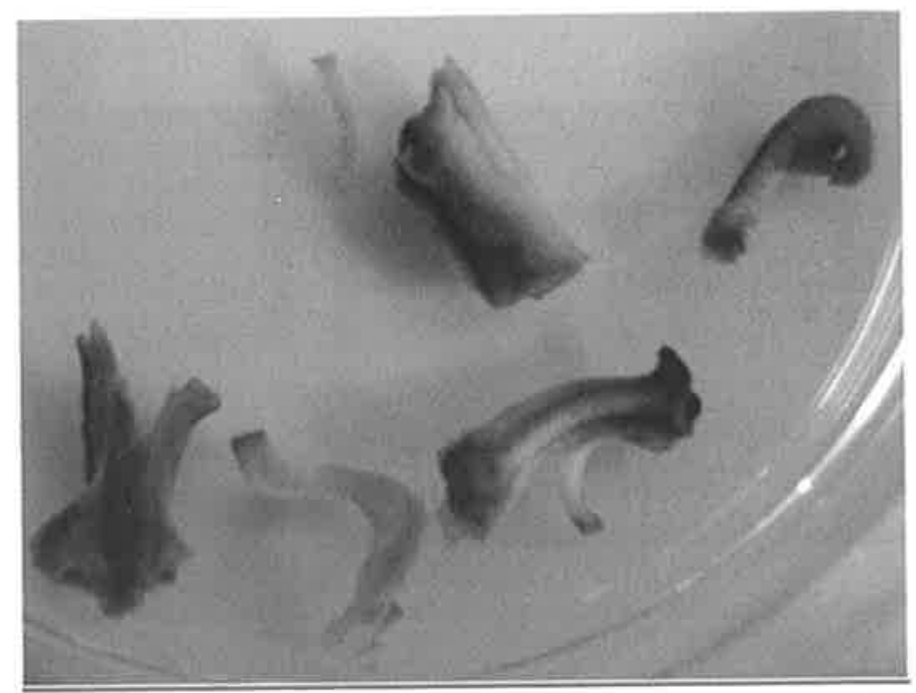

Fig. 3. Expression of GUS in cauliflower plants after transformation of cauliflower with Agrobacterium-carrying APX gene.

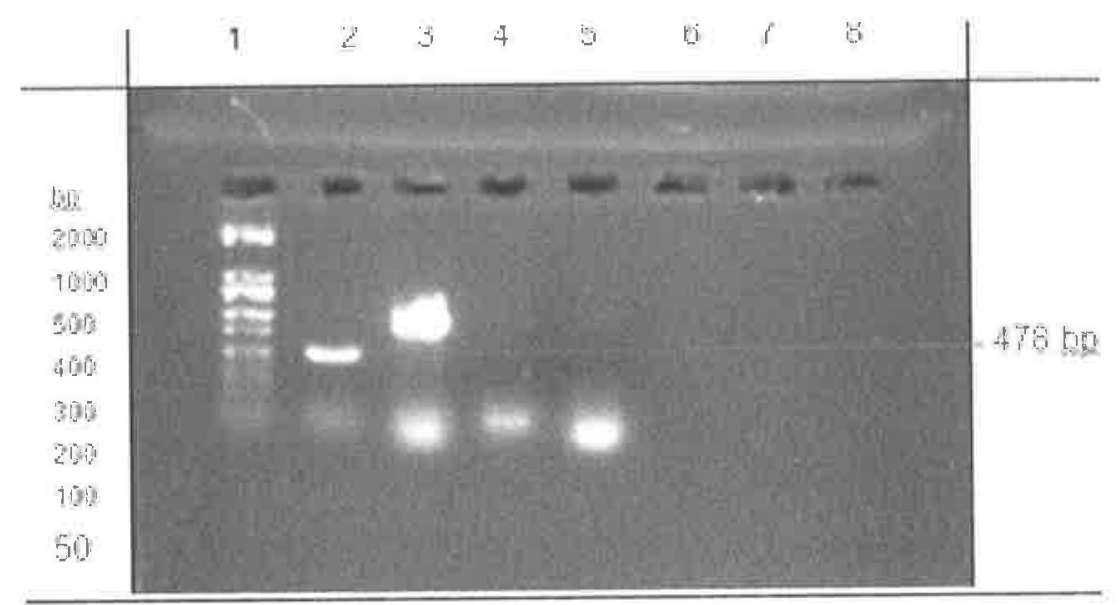

Fig. 4. Analysis of the presence of APX gene in putative transgenic plant. DNA molecular size marker (line 1), transformed plant carrying APX gene (lanes 2 and 3), negative control (non-transformed cauliflower leaves) (lanes 4 and 5) and water (lanes 6 and 7). 